\title{
Palliative therapy in adults with cancer: a cross-sectional study
}

\author{
A terapêutica paliativa em adultos com câncer: um estudo transversal \\ La terapéutica paliativa en adultos con cáncer: un estudio transversal
}

\section{Angelita Visentin', Maria de Fátima Mantovani', Luciana Puchalski Kalinke', Shirley Boller', Leila Maria Mansano Sarquis'}

' Universidade Federal do Paraná, Postgraduate Program in Nursing. Curitiba, Paraná, Brazil.

How to cite this article:

Visentin A, Mantovani MF, Kalinke LP, Boller S, Sarquis LMM. Palliative therapy in adults with cancer: a cross-sectional study. Rev Bras Enferm [Internet]. 2018;71(2):252-8. DOI: http://dx.doi.org/10.1590/0034-7167-2016-0563

Submission: 11-10-2016 Approval: 04-04-2017

\begin{abstract}
Objective: To characterize the socioeconomic and clinical profile of adult cancer patients in palliative therapy. Method: Cross-sectional study in an oncology hospital in Paraná, with 124 adult patients who started palliative therapy in the period from Jan. 2 to June $30,2015$. Results: Of the participating population, $60.5 \%$ were women, $68.5 \%$ white, $48.4 \%$ married, $72.6 \%$ catholic and with income of one to two minimum wages. Non-smokers, $45.2 \%$, non-alcoholics $75 \%$, and $92 \%$ had Performance Status 1 and 2 . The predominant primary diagnosis was breast cancer, with previous chemotherapy and radiotherapy. The sites of metastasis were lung/mediastinum/bronchi and lymph nodes. Conclusion: The socioeconomic and clinical context characterized the profile of adult patients in palliative therapy. The demand arising from the increase in cases of advanced cancer requires nursing care at all stages of treatment.
\end{abstract}

Descriptors: Cancer; Socioeconomic Factors; Palliative Care; Oncology Nursing; Adult.

\section{RESUMO}

Objetivo: caracterizar o perfil socioeconômico e clínico dos pacientes oncológicos adultos na terapêutica paliativa. Método: estudo transversal realizado em um hospital de oncologia no Paraná, com 124 pacientes adultos que iniciaram a terapêutica paliativa no período 2 de janeiro a 30 de junho de 2015. Resultados: da população participante, 60,5\% era do sexo feminino, 68,5\% branca, $48,4 \%$ casada, $72,6 \%$ de religião católica e com renda de um a dois salários mínimos. Não tabagistas, 45,2\%, 75\% não etilistas, e $92 \%$ apresentam Performance Status 1 e 2 . O diagnóstico do câncer primário prevalente foi mama, com tratamento prévio de quimioterapia e radioterapia. Os locais de metástase foram pulmão/mediastino/brônquios e linfonodos. Conclusão: o contexto socioeconômico e clínico apresentado caracterizou o perfil dos pacientes adultos na terapêutica paliativa. A demanda que advém do aumento dos casos de câncer avançado requer a atenção da enfermagem em todas as fases do tratamento.

Descritores: Câncer; Fatores Socioeconômicos; Tratamento Paliativo; Enfermagem Oncológica; Adulto.

\section{RESUMEN}

Objetivo: caracterizar el perfil socioeconómico y clínico de los pacientes oncológicos adultos en la terapéutica paliativa. Método: estudio transversal realizado en un hospital de oncología en Paraná, Brasil, con 124 pacientes adultos que iniciaron la terapéutica paliativa desde el 2 de enero hasta el 30 de junio de 2015. Resultados: de la población participante, 60,5\% era del sexo femenino; $68,5 \%$ blanca; $48,4 \%$ casada; y 72,6\% de religión católica y con renda de un a dos salarios mínimos. No fumadores, 45,2\%; 75\% no alcohólicos; y 92\% presentan Escala de Rendimiento de Karnofsky 1 y 2 . El diagnóstico del cáncer primario prevalente fue de mama, con tratamiento previo de quimioterapia y radioterapia. Los locales de metástasis fueron pulmón/mediastino/bronquios y ganglios linfáticos. Conclusión: el contexto socioeconómico y clínico presentado caracterizó el perfil de los pacientes adultos en la terapéutica paliativa. La demanda que resulta del aumento de los casos de cáncer avanzado requiere la atención de la enfermería en todas las fases del tratamiento.

Descriptores: Cáncer; Factores Socioeconómicos; Tratamiento Paliativo; Enfermería Oncológica; Adulto. 


\section{INTRODUCTION}

Health inequalities reflect social inequalities. Regarding cancer, socioeconomic differences are manifested in several aspects of the epidemiological profile. Lower socioeconomic levels have shown a higher incidence of late diagnosis which could be subject to screening -, and greater difficulties in access to diagnostic tests and available treatments for the disease, resulting in poorer prognosis with shorter survival ${ }^{(1)}$.

Cancer is expressed as a result that correlates multifactorial health determinants and conditions related to economic, sociocultural, personal experience and lifestyle aspects. Risk factors such as smoking, harmful alcohol consumption, physical inactivity, unhealthy diet and interfaces with the environment where the individual is, can influence the possibilities of cancer development ${ }^{(2)}$.

In Brazil, the National Cancer Institute José Alencar Gomes da Silva (Inca) foresees 600 thousand new cases of cancer for the 2016-2017 biennium, due to early diagnosis and screening, and a significant inversion of the age pyramid is added as potentiator of these indicators ${ }^{(3)}$.

Socioeconomic, regional and individual indicators are independent predictors of incidence, diagnosis, treatment and prognosis of oncological diseases ${ }^{(4)}$. Studies related to these complexities have updated their concepts. Once called "individual risk factors," they now have broader approaches that favor the profile of access to public policies, consumption patterns and social interaction networks ${ }^{(5)}$.

Despite major advances in cancer treatment, healing is not always possible and the result is shown in the ascending slope of incidence and mortality of cancer cases in Brazil ${ }^{(6)}$. With this scenario, the World Health Organization (WHO) increasingly recommends that the approach to people in later life be programmed and planned in order to comprehensively meet the multiplicity of problems presented ${ }^{(7)}$.

The National Academy of Palliative Care (ANCP) defined Palliative Action as a therapeutic measure without curative intent that aims to reduce the negative repercussions of diseases, being "an integral part of the practice of the health professional, regardless of the disease or its stage of evolution. It can be provided already in primary care in situations of irreversible medical condition or chronic progressive disease"(8).

It is reiterated that knowing and understanding the different profiles of adult patients undergoing palliative therapy is necessary in order to offer the patient and his family a better understanding of the progression of the disease so that they can participate in the decisions related to therapeutic alternatives in the control of symptoms. It also allows the team to evaluate the patient individually and help resolve conflicts and problems, easing the anguish caused by physical, mental, emotional, social and spiritual suffering in this life period ${ }^{(9)}$.

The necessary recognition of the population that should receive palliative therapy and their socioeconomic and clinical characterization manifest aspects of the population profile that allow to target promotion and prevention campaigns and actions, early diagnosis and treatment, alongside the essential role of nursing.
There is no denying the value of individualized assistance to alleviate the suffering that precedes the end of life. Therefore, providing the care, guidance and education for patients with advanced cancer and their families represents a significant challenge for nurses. Helping in the experience of the disease process, clinical conduct and rehabilitation and in the direct relation with the quality of life (QoL) of all those involved in the advanced cancer process in palliative therapy is at the core of the expected nursing actions in this treatment modality.

Most studies identified in the literature do address palliative care, but there is a shortage of articles that portray the profile of the population in palliative care. In this context, this study aimed to characterize the socioeconomic and clinical profile of adult oncology patients in palliative therapy.

\section{METHOD}

\section{Ethical aspects}

Because it is a study involving humans, the research project was approved by the Research Ethics Committee of Hospital Erasto Gaertner.

\section{Design, place of study and period}

A cross-sectional study conducted in a reference hospital in oncology care in Paraná. In this institution there is a Palliative Care Service where patients can be referred to by any specialty/service and carry out the concomitant treatment. This Service has reserved beds for patients who are seen in the hospital and/or at home, and promotes multidisciplinary meetings that allow the exchange of experiences about the treatments and care to be delivered. It is a recruitment for convenience, census and sample by adherence. The study was conducted from January 2 to June 30, 2015.

\section{Population or sample; inclusion and exclusion criteria}

We enrolled 124 patients who started palliative treatment on any day from January 2 to June 30, 2015, with the following inclusion criteria: adults (between 20 and 59 years) with diagnosis of any histological type of cancer confirmed by biopsy and that were included and communicated about oncological palliative therapy as recorded in the patient's medical record. Exclusion criteria were the patient's inability to maintain verbal and/or written communication.

\section{Study Protocol}

The data collection was carried out in three stages: a) on the first day of the week, the researcher consulted the list of patients who would initiate chemotherapy and/or palliative radiotherapy; b) on the day scheduled for treatment initiation, the researcher administered the ICF in a reserved office and in the hour preceding the treatment; c) subsequently, the patient's chart was checked for inclusion criteria.

The research instrument was developed by the researchers and identified as a socioeconomic and clinical characterization of the patient in oncological palliative therapy with the following variables: age, sex, weight, height, color, education, marital status, religion, number of household members, smoking, 
alcoholism, cancer, diagnosis of primary tumor, previous treatments, site(s) of metastasis and the scale of the Eastern Cooperative Oncology Group Performance Status (ECOG), which evaluates how the disease affects a patient's daily living abilities, with scores ranging from zero to five points ${ }^{(10)}$.

\section{Analysis of results and statistics}

The data were entered into Microsoft Excel 2013 and presented in contingency tables, in absolute numbers and frequency. The data sheet was exported to SPSS software, version 18.0, for processing the analyses. The results appear in absolute numbers and percentages and $p$ value for the variables of interest.

\section{RESULTS}

The population was characterized as: $60.5 \%(\mathrm{n}=75)$ women; 68.5\% ( $\mathrm{n}=85)$ white; 48.4\% ( $\mathrm{n}=60)$ married; $72.6 \%(n=90)$ of Catholic religion; and 55.7\% $(n=69)$ without income or income of one to two minimum wages. Regarding life habits, $45.2 \%(\mathrm{n}=56)$ are characterized as nonsmokers; $75 \%$ ( $n=94)$ as non-alcoholics; and 92\% ( $=114)$ with Performance Status 1 and 2. Diagnosis of the prevailing primary neoplasm was breast, with previous chemotherapy and radiotherapy, and the metastasis sites found were lung/ mediastinum/bronchi and lymph nodes.

Regarding alcohol consumption, $75.8 \%(n=94)$ were non-alcoholics. Of those who responded affirmatively, consumption ranged from 5 to 10 doses per day, and 9 (28.1\%) indicated length of consumption of more than one year, divided into the categories shown in Table 1, which highlights the variables studied in order to interpret the results from the socioeconomic characterization of the patients who started palliative therapy in a reference institution in cancer care.

Regarding housing conditions, we identified the following: with own house $(56.5 \%)$, assigned house $(22.6 \%)$ and rented house $(21 \%)$; masonry $(74.2 \%)$, wooden $(25 \%)$, and other $(0.8 \%)$; with light and water $(97.6 \%)$, and without water and without light $(2.4 \%)$. Regarding smoking, $41.1 \%(n=52)$ were smokers, of these, $55.1 \%(n=38)$ declared themselves smokers for more than 10 years, $37.7 \%(\mathrm{n}=26)$ smoke 10 to 20 cigarettes per day, and $40.6 \%$ ( $n=28$ ) reported smoking more than 20 cigarettes per day.

According to Table 2, the predominance of infiltrating ductal carcinoma of the breast occurred in $22.6 \%(n=28)$, carcinoma and adenocarcinoma $28.2 \%$ and $26.6 \%$, respectively (n $=35$ and $n=33)$, and melanoma $8.1 \%$ of the cases $(n=10)$. When the primary diagnosis was related to ECOG, ECOG 3 was found to be more present in breast and stomach cancers.

Among the clinical characterization of previous treatments for cancer performed before the beginning of palliative therapy, chemotherapy was present in $62.7 \%(\mathrm{n}=78)$ of the cases, and surgery represented $46 \%(n=57) ; 24.2 \%(n=30)$ of the patients did not undergo any previous treatment. The most affected sites of metastasis in the sample were: lymph nodes, with $48.4 \%$ ( $n=60)$; lung/mediastinum/bronchi, 45.2\% ( $n=56)$; liver/pancreas, $26.6 \%(n=33)$; bone, $41.1 \%(n=51)$; and brain/central nervous system, $25.8 \%(\mathrm{n}=32)$. It should be noted that some patients had more than one site of metastasis.
Table 1 - Socioeconomic distribution of adult patients in palliative therapy, from January to June 2015 in a cancer hospital in Curitiba, Paraná, Brazil

\begin{tabular}{|c|c|c|c|}
\hline & $\mathbf{n}$ & $\%$ & $p$ value \\
\hline \multicolumn{4}{|l|}{ Age group } \\
\hline 40 to 59 & 102 & 82.3 & \multirow{2}{*}{$<0.001$} \\
\hline 19 to 39 & 22 & 17.7 & \\
\hline \multicolumn{4}{|l|}{ Sex } \\
\hline Female & 75 & 60.5 & \multirow{2}{*}{$<0.001$} \\
\hline Male & 49 & 39.5 & \\
\hline \multicolumn{4}{|l|}{ Color } \\
\hline White & 85 & 68.5 & Ref. \\
\hline Mixed-race & 19 & 15.3 & $<0.001$ \\
\hline Black & 20 & 16.1 & $<0.001$ \\
\hline
\end{tabular}

Marital Status

Married

Divorced

Concubinage

Single

Widower

$60 \quad 48.4 \quad$ Ref

$\begin{array}{lll}11 & 8.9<\mathbf{0 . 0 0 1}\end{array}$

$17 \quad 13.7<\mathbf{0 . 0 0 1}$

$33 \quad 26.6<\mathbf{0 . 0 0 1}$

$3 \quad 2.4<\mathbf{0 . 0 0 1}$

Religion

Catholic

Spiritist

Other

Protestant

Evangelical

$\begin{array}{ccc}90 & 72.6 & \text { Ref. } \\ 9 & 7.3 & <\mathbf{0 . 0 0 1} \\ 3 & 2.4 & <\mathbf{0 . 0 0 1} \\ 3 & 2.4 & <\mathbf{0 . 0 0 1} \\ 19 & 15.3 & <\mathbf{0 . 0 0 1}\end{array}$

Economic class

No income

Less than 1 minimum wage

From 1 to 2 minimum wages

From 2 to 4 minimum wages

From 4 to 6 minimum wages

More than 6 minimum wages

Did not know

$\begin{array}{ccc}8 & 6.5 & <\mathbf{0 . 0 0 1} \\ 18 & 14.5 & <\mathbf{0 . 0 0 1} \\ 43 & 34.7 & \text { Ref. } \\ 33 & 26.6 & 0.168 \\ 16 & 12.9 & <\mathbf{0 . 0 0 1} \\ 5 & 4.0 & <\mathbf{0 . 0 0 1} \\ 1 & 0.8 & <\mathbf{0 . 0 0 1}\end{array}$

Education

Some elementary school
Elementary school
Some high school
High school
Some college
College

$\begin{array}{ccc}38 & 30.6 & \text { Ref. } \\ 36 & 29.0 & 0.781 \\ 5 & 4.0 & <\mathbf{0 . 0 0 1} \\ 31 & 25.0 & 0.321 \\ 6 & 4.8 & <\mathbf{0 . 0 0 1} \\ 8 & 6.5 & <\mathbf{0 . 0 0 1}\end{array}$

The results of the relations and/or associations are shown with absolute values and percentages in the same table. This shows the joint distribution of the variables for absolute and percentage values between all combinations. To check whether or not there is an association, one should study the values in percentages. Thus, we compare the distribution of the total column with the distribution of the other (middle) columns. If there is any value per line that is very different from the value of the total column, there is an association and/or statistical dependency. 
Table 2 - Relationship of age with Eastern Cooperative Oncology Group Performance Status (ECOG), site of metastases, type of cancer and previous treatment of adult patients in palliative therapy, from January to June 2015 in a cancer hospital in Curitiba-Paraná, Brazil

\begin{tabular}{|c|c|c|c|c|c|c|c|c|}
\hline \multirow{2}{*}{ Age group } & & \multicolumn{2}{|c|}{19 to 39} & \multicolumn{2}{|c|}{40 to 59} & \multicolumn{2}{|c|}{ Total } & \multirow{2}{*}{$\begin{array}{c}p \\
\text { value }\end{array}$} \\
\hline & & $\mathbf{n}$ & $\%$ & $\mathbf{n}$ & $\%$ & $\mathbf{n}$ & $\%$ & \\
\hline \multirow{3}{*}{ ECOG } & ECOG 1 & 11 & 50 & 47 & 46 & 58 & 47 & \multirow{3}{*}{0.904} \\
\hline & ECOG 2 & 9 & 41 & 47 & 46 & 56 & 45 & \\
\hline & ECOG 3 & 2 & 9 & 8 & 8 & 10 & 8 & \\
\hline \multirow{9}{*}{$\begin{array}{l}\text { Site(s) of } \\
\text { metastasi(e)s }\end{array}$} & Adrenal & - & - & 5 & 2 & 5 & 2 & \multirow{9}{*}{0.357} \\
\hline & Cerebral & 8 & 17 & 24 & 11 & 32 & 12 & \\
\hline & Gastrointestinal & 4 & 9 & 11 & 5 & 15 & 5 & \\
\hline & Genitals & 2 & 4 & 13 & 6 & 15 & 5 & \\
\hline & Hepatic & 2 & 4 & 31 & 14 & 33 & 12 & \\
\hline & Lymph nodes & 9 & 19 & 51 & 22 & 60 & 22 & \\
\hline & Bone & 7 & 15 & 44 & 19 & 51 & 19 & \\
\hline & Lung & 13 & 28 & 43 & 19 & 56 & 20 & \\
\hline & Urinary & 2 & 4 & 6 & 3 & 8 & 3 & \\
\hline \multirow{6}{*}{ Type of cancer } & Adenocarcinoma & 2 & 13 & 33 & 33 & 35 & 30 & \multirow{6}{*}{0.013} \\
\hline & Carcinoma & - & 4 & 29 & 29 & 33 & 28 & \\
\hline & Infiltrating Ductal Carcinoma & 3 & 19 & 25 & 25 & 28 & 24 & \\
\hline & Lymphoma & 2 & 13 & 3 & 3 & 5 & 4 & \\
\hline & Melanoma & 2 & 13 & 8 & 8 & 10 & 9 & \\
\hline & Osteosarcoma & 3 & 19 & 2 & 2 & 5 & 4 & \\
\hline \multirow{5}{*}{$\begin{array}{l}\text { Previous } \\
\text { treatment(s) }\end{array}$} & Surgery & 10 & 29 & 47 & 26 & 57 & 26 & \multirow{5}{*}{0.494} \\
\hline & Hormone therapy & - & - & 12 & 7 & 12 & 6 & \\
\hline & No previous treatment & 6 & 17 & 24 & 13 & 30 & 14 & \\
\hline & Chemotherapy & 14 & 40 & 64 & 35 & 78 & 36 & \\
\hline & Radiotherapy & 5 & 14 & 36 & 20 & 41 & 19 & \\
\hline
\end{tabular}

Note: ECOG - Eastern Cooperative Oncology Group Performance Status

At the junction between two age groups, only in relation to the type of cancer was there a statistically significant difference for adenocarcinoma in the population aged 40 to 59 years, and osteosarcoma for adults aged 19 to 39 years.

\section{DISCUSSION}

Participants in the study were characterized as married or in concubinage, living in dwellings with minimum living conditions (light and water), and more than four people living in the same place. Those are understood as factors that can help patients in palliative therapy by inferring that they have a support network who helps them meet the needs arising from the treatment of advanced cancer.

There are reports that a higher percentage of women with lung, bronchial, genital system and other types of cancer in advanced stages of primary diagnosis was associated with a greater degree of socioeconomic deprivation ${ }^{(11)}$. In the results of this research, eight $(6.5 \%)$ participants - of these, four women - reported having no income. Added to the $49.2 \%$ of the study participants $(n=61$ ) who earn less than one and up to two minimum wages, women are $70.49 \%(n=43)$ and account for $34.67 \%$ of all participants in the study.
The results show that the search for palliative therapy was predominantly by Catholic white women who have elementary education and live in their own homes of masonry supplied with water and light. Consistent results indicate a higher incidence and mortality from breast cancer and mortality from colon cancer in women, positively associated with socioeconomic status and living area ${ }^{(1)}$.

For the vast majority of diseases, including cancer, the influence of social, economic and cultural inequalities and racial issues is evident. In the study, by analyzing the race reported by participants, $31.5 \%$ ( $\mathrm{n}=39$ ) are black or mixedrace. The ethnic groups also affect the incidence and mortality from cancer and often racial disparities are striking and can result from biological/genetic factors or from the environment. Mortality rates for most common cancers are higher among blacks compared to any other ethnic/racial group. And gender should be considered too ${ }^{(5)}$.

With regard to gender issues, it can be observed that in Brazil, public policies are mostly geared to women's health rather than to men's health. For example: reduction of maternal mortality, prevention of breast cancer, campaign against HPV (Human Papilloma Virus), among others. Nevertheless, the exponential number of cases of cancer is found in women ${ }^{(4)}$.

This information corroborates the data found in this study: $60.5 \%(n=75)$ of women and 39.5\% ( $n=49)$ of men started palliative cancer therapy. A woman with low income, low education, no private health insurance, without a partner, resident in a rural area or further away from the place for medical examinations is less likely to seek preventive care for diseases such as cancer ${ }^{(4)}$. The data from the study corroborate the description above and it is added that the hospital where the study was performed provides care to cancer patients from several cities in Paraná, including residents from distant and rural locations, which may have contributed to the results.

In women, the association between the incidence of breast cancer and the high socioeconomic status has been mainly explained by the higher prevalence of reproductive factors in the richer classes, such as lower age at menarche, lower parity, higher age at first birth and menopause, among others. And the low socioeconomic level, to which aspects of sexual 
behavior linked to women's greater likelihood of acquiring or becoming a chronic carrier of HPV are mainly related, such as early age of the first sexual intercourse and multiple sexual partners, as well as the lower number of preventive screening exams ${ }^{(1)}$.

In a study of 482 patients, the characterization found a mean age of 59 years (range 26-95). Of these, 67\% were women, and the mean KPS was 80 (range 40-100). The most common sites of primary cancer were breast (59\%), prostate $(17 \%)$ and lung $(10 \%)$, with $57 \%$ of patients receiving systemic treatment and $23 \%$ having visceral metastases. Bone metastases are a frequent complication of advanced cancer that occurs in approximately $50 \%$ of patients with metastatic cancer $^{(12)}$. In this study, bone/spinal metastases accounted for $41.1 \%(n=51)$ of the 124 participating patients.

For men, the higher the socioeconomic level of the area of residence, the higher the mortality from lung cancer and the higher the incidence of prostate cancer. There is an association between lower socioeconomic level of residence area and increased mortality and incidence of esophageal and stomach cancer, incidence of colon and lung cancer, and mortality from larynx and oral cavity cancer ${ }^{(1)}$.

In this study, the religion most mentioned by the participants was Catholic, although others were also reported, such as Protestant, Spiritist, Jewish and Evangelical. In a survey, it was observed that $50 \%$ of the patients lived with the spouse or children, and that these interfered with the acceptance of the proposed treatments and the QoL. Patients demonstrate in the results the importance of social support and religion ${ }^{(13)}$. These and other information highlight the importance of the relationships observed between individual and collective variables and their interference in the processes of diagnosis and treatment of advanced cancer, in particular.

The aspects described characterize the patients of the study as low income and low schooling. These characteristics, together with the difficulties that emerge from this profile - such as the lack of financial and structural conditions for the diagnostic tests for cancer - may have reflected in the late search for care and the diagnosis of advanced cancer. Relevant and priority factors for performing preventive tests for cancer include: age, education, income, race, marital status, type of health system used and distance to cover to perform the tests ${ }^{(4)}$.

The data show that most of the patients in palliative therapy in the study are women, in the age group 40-59 years of age. Similar results were found in another study conducted in an outpatient clinic of palliative chemotherapy in Belo Horizonte, $M^{(14)}$. Inca estimates for the 2016-2017 biennium indicate the emergence of 384,430 new cases of cancer in women across Brazil, and in the state of Paraná, 23,590 new cases are foreseen ${ }^{(3)}$. This data reflects, in part, the larger number of women in palliative care. On the other hand, it is already well established in the literature that the female sex is associated with a higher demand for medical services, either because women easily realize the risks to their health or by understanding that care is inherent to the female sex ${ }^{(15-17)}$.

The data found show that there are more patients with low level of schooling and income in palliative treatment. These characteristics, together with the difficulties that emerge from this profile, such as the lack of financial and structural conditions for performing the diagnostic tests for cancer, may have reflected in the late search for care and the diagnosis of advanced cancer. People with low level of education will certainly have difficulty understanding health information, and therefore, the team that works in palliative therapy finds in this profile the possibility of addressing this deficiency. It is understood that people with higher incomes and levels of schooling seek health services well in advance of the evolution of cancer.

Socioeconomic factors and structuring of health services include aspects related to different levels of exposure to risk conditions and access to diagnosis, treatment and prevention. These factors explain, for example, the differences in cancer mortality between socioeconomic and ethnic groups, as well as the difference in survival rates for most tumors in men and women. They are also determinants of inequalities in cancer, observed not only across countries, but also within the same country, and can be present in dissimilar ways ${ }^{(5)}$.

The literature has suggested that socioeconomic and community or neighborhood characteristics can significantly affect people's health, regardless of their individual traits. This effect is mediated by risk factors related to access to health and treatment services, educational and social assistance institutions, and cultural apparatuses, quality of housing, local physical and public safety conditions, and cultural and social habits, among others ${ }^{(1)}$.

Limitations of access to health services can be expressed in a variety of ways, including: financial/economic conditions, marital status (not having a spouse - being single, separated or widowed - is related to the difficulties of moving and to the duties that surround leaving the place of residence or work), not having private health insurance, limited transportation and cultural and geographical barriers ${ }^{(5)}$.

An example of the limitation of access to health services is the age criterion, which, as a result of population aging, places older people as a priority in the care and provision of resources, just to name one of the points. The study has shown that the adult population requires expenditure of resources. They are demanding attention to campaigns, prevention examinations and appropriate treatments. Cancer demands a redefinition of living standards (socioeconomic conditions), often based on the adult population that provides income and is economically active. It is also noteworthy that adults are prone to a variety of causal factors related to cancer, such as stress, poor diet, risky sexual behavior and unhealthy lifestyle habits, such as smoking, drinking and illegal drug use.

Cancers of the oral cavity, pharynx, esophagus and larynx have been mainly related to smoking habits, alcohol consumption and diet poor in fruits and vegetables - more prevalent in the poorer classes. Eating habits such as high consumption of red meat and fats and low in fruits and vegetables, physical inactivity, obesity, and alcohol consumption have been identified as major risk factors for the development of various types of ancer ${ }^{(1)}$

Alcohol and tobacco consumption became a constant 
theme in campaigns and actions aimed at cancer prevention and, because of their importance and their connections, this issue was addressed in the research. In the study, of the 24 participants who confirmed to be alcoholics, 13 were men $(10.48 \%)$ and 11 were women $(8.87 \%)$. These are understood to be very close numbers because, historically, men declare themselves as more frequent consumers of alcohol than women do, and this is a reality that has changed gradually.

In Brazil, the percentage of the population aged 18 years or older who consumed alcoholic beverages once a week or more was $24 \%$, ranging from $18.8 \%$ in the North to $28.4 \%$ in the South. Among men, the proportion was $36.3 \%$, while among women it was $13 \%$. In adults with higher levels of education, especially those with college degrees, this percentage was $30.5 \%$, while in adults with no schooling and incomplete elementary school, it was $19 \%{ }^{(18)}$.

According to Inca data, the National Health Survey (PNS), carried out in the second half of 2013, found that $14.5 \%$ of adults smoked regular cigarettes and $12.7 \%$ were daily smokers of some tobacco product, $16.2 \%$ of whom were men and $9.7 \%$ women $^{(3)}$. In the present study, of the 52 participants who self-reported as smokers, $49 \%(n=24)$ were men and $37 \%(n=28)$ were women.

Social changes have a considerable impact on the risk factors for cancer development. Women are increasing exponentially both in social participation and as concerns alcohol and tobacco use. The transformations between services culturally intended for women and now taken by men, and vice versa, place women before unprecedented realities. Exposure to stress, poor diet, low reproductive potential and economic demands can serve as examples of this. There remains less availability and, sometimes, perceived relevance to caregiving actions. Although historically women seek health services more often than men do, as the research has shown, cancer was already at an advanced stage.

In 2013, the PNS estimated that $1.8 \%$ of people 18 years of age or older (2.7 million adults) reported a medical diagnosis of cancer in Brazil. The most frequent types were breast (reported by $39.1 \%$ of women), skin ( $16.2 \%$ of adults), prostate (36.9\% of men) and cervix (11.8\% of women). The proportion in the urban area was significantly higher than in the rural area: $1.9 \%$ and $1.2 \%$, respectively. The South region showed the highest percentage of medical diagnosis of cancer $(3.2 \%)$, followed by the Southeast (2.1\%) and Central West (1.6\%). The North and Northeast regions, on the other hand, presented the lowest prevalence, at the level of $0.9 \%$. Data from this study partially corroborate the information reported ${ }^{(18)}$.

A study that aimed to describe the characteristics, treatments and survival of lung cancer patients identified that $59.9 \%$ of the patients received palliative therapy. It is reiterated that, of those mentioned, most of the 236 patients presented diagnosis in advanced stages ${ }^{(6)}$. In this study, all of the patients had clinical stage IV, and lung cancer cases accounted for $6.5 \%$. However, it is understood that age limitation, which represented the median of 47.98 years (range 19-59), and the sample's size contributed to these results, as in the mentioned study, the median age was 65 years (range 27-92) and 566 patients.
Upon a diagnosis of cancer, the performance status scale ECOG should be considered. Developed by Oken and other authors, its scores range from zero to five points, and it evaluates how the disease affects the patient's daily living abilities ${ }^{(10)}$. Patient Performance Status information during oncological palliative therapy is a predictor of patient response to treatment and impact on quality of life.

In this analysis, of the 124 patients included, 46.8\% ( $=$ 58) had ECOG 1 (restricted for strenuous physical activity, but able to perform mild work or of sedentary nature); $45.2 \%$ (n = 56) ECOG 2 (fully capable of self-care but unable to perform any work activities, out of bed for more than $50 \%$ of the time); and $8.1 \%(\mathrm{n}=10)$ ECOG 3 (limited self-care capacity, confined to the bed or the chair more than $50 \%$ of waking time). A study considering predictive criteria for survival in patients in palliative treatment mentioned 12 variables, including sex, age, site of primary tumor and $\operatorname{ECOG}^{(10,18)}$.

The percentage of patients with advanced cancer and low Performance Status can describe the current oncological health picture in Brazil and be a reflection of the inefficiency of the assistance and control programs of this disease. It is impossible to overtly implement a screening program for the target population, with an insufficient health care services network to provide the necessary diagnosing and treatment equipment for cancer patients. This picture reflects the epidemiological importance and relevance of palliative care for cases of advanced disease, either in the diagnosis or in its progression ${ }^{(5)}$.

Changes in the socioeconomic and clinical profile of cancer patients serve as support for implementing major changes in public policies and organization of health services. In relation to cancer palliative therapy and its precepts, they work as support for the proposal of new technologies and new forms of care that go beyond the preconceived ones, while considering the impact from diagnosis to various forms of treatment, cost-effectiveness and resource allocation.

\section{Limitations of the study}

However, there were limitations in the development of this study in relation to sample size and from having been conducted in only one cancer care institution, with predominant profile of care provided through the Brazilian Unified Health System (SUS). Thus, the data presented cannot be generalized to other realities.

\section{Contributions to the field of nursing, health or public policy}

Knowledge of the socioeconomic and clinical profile of patients undergoing palliative therapy allows the provision of differentiated care in this phase of cancer treatment. Care planning can be improved in such a way to reduce possible therapy-related complications and increase patient adherence. In addition, the nurse-patient connection is thus favored, as there is a mutual recognition. It is important that the nurse carries out educational activities to improve understanding of the disease and the patient's QoL.

\section{CONCLUSION}

The socioeconomic and clinical profile of patients who initiate palliative therapy presented in this study is predominantly 
of low-income women. The types of cancer identified as prevalent were carcinoma and adenocarcinoma, and the prevailing sites of primary tumors were breast and colon-rectum.
There is a connection between socioeconomic factors of adult patients who started palliative therapy and the description of the literature on the subject.

\section{REFERENCES}

1. Ribeiro AA, Nardocci AC. Desigualdades socioeconômicas na incidência e mortalidade por câncer: revisão de estudos ecológicos, 1998-2008. Saúde Soc [Internet]. 2013 [cited 2016 Jul 12];22(3):878-91. Available from: http://www.inca.gov.br/estimativa/2016/ estimativa-2016-v11.pdf

2. Brasil. Ministério da Saúde. Plano de ações estratégicas para o enfrentamento das doenças crônicas não transmissíveis (DCNT) no Brasil 2011-2022 [cited 2016 Jan 17]. Available from: http://bvsms.saude.gov.br/bvs/publicacoes/plano_acoes_enfrent_dcnt_2011.pdf

3. Instituto Nacional de Câncer José Alencar Gomes da Silva. Estimativa 2016: incidência de câncer no Brasil [Internet]. Rio de Janeiro: Ministério da Saúde; 2015 [cited 2016 Jan 17]. Available from: http://www.inca.gov.br/estimativa/2016/estimativa2016-v11.pdf

4. Sadovsky AI, Poton WL, Reis-Santos B, Barcelos MRB, Silva ICM. Índice de Desenvolvimento Humano e prevenção secundária de câncer de mama e colo do útero: um estudo ecológico. Cad Saúde Pública [Internet]. 2015 [cited 2016 Sep 17];31(7):1539-50. Available from: http://www.scielo.br/pdf/csp/v31n7/0102-311X-csp-31-7-1539.pdf

5. Barbosa IR, Costa ICC, Pérez MMB, Souza DLB. As iniquidades sociais e as disparidades na mortalidade por câncer relativo ao gênero. Rev Ciênc Plural [Internet]. 2015 [cited 2016 Jul 12];1(2):79-86. Available from: https://periodicos.ufrn.br/rcp/article/ view/7618/5660

6. Araujo LHL, Baldotto CS, Zukin M, Vieira FMAC, Victorino AP, Rocha VR, et al. Survival and prognostic factors in patients with Non-Small Cell Lung Cancer treated in the private health care. Rev Bras Epidemiol [Internet]. 2014 [cited 2016 Jul 12];17(4):100114. Available from: http://www.scielo.br/pdf/rbepid/v17n4/1415-790X-rbepid-17-04-01001.pdf

7. Word Health Organization. Definition of Palliative Care [Internet]. Geneva: WHO; 2005 [cited 2016 Aug 15]. Available from: http://www.who.int/cancer/palliative/definition/en/

8. Maciel MGS, Rodrigues LF, Naylor C, Bettega R, Barbosa SM, Burlá C, et al. Critérios de qualidade para cuidados paliativos no Brasil: documento elaborado Academia Nacional de Cuidados Paliativos. Rio de Janeiro: Diagraphic; 2006.

9. Menezes RA, Barbosa PC. A construção da "boa morte" em diferentes etapas da vida: reflexões em torno do ideário paliativista para adultos e crianças. Ciênc Saúde Colet [Internet]. 2013 [cited 2016 Jul 12];18(9):2653-62. Available from: http://www.redalyc. org/articulo.oa? id $=63028227020$

10. Oken M, Creech R, Tormey D, Horton J, Davis TE, McFadden ET, et al. Toxicity and response criteria of the Eastern Cooperative Oncology Group. Am J Clin Oncol [Internet]. 1982 [cited 2017 Aug 25];5(6):649-55. Available from: https://www.ncbi.nlm.nih. gov/pubmed/7165009

11. Philips BU Junior, Belasco E, Markides KS, Gong G. Socioeconomic deprivation as a determinant of cancer mortality and the Hispanic paradox in Texas, USA. Int J Equity Health[Internet]. 2013 [cited 2016 Apr 20];12(26):1-9. Available from: https:// equityhealthj.biomedcentral.com/articles/10.1186/1475-9276-12-26

12. Silva NM, Piassa MP, Oliveira RMC, Duarte MSZ. Depressão em adultos com câncer. Ciênc Atual [Internet]. 2014 [cited 2016 Apr 20];3(1):2-14. Available from: http://inseer.ibict.br/cafsj/index.php/cafsj/article/view/48/pdf

13. Souza RS, Simão DAS, Lima EDRP. Perfil sociodemográfico e clínico de pacientes atendidos em um serviço ambulatorial de quimioterapia paliativa em Belo Horizonte. Rev Min Enferm [Internet]. 2012 [cited 2016 Mar 14];16(1):38-47. Available from: http://reme.org.br/exportar-pdf/498/v16n1a06.pdf

14. Leite JF, Dimenstein M, Paiva R, Carvalho L, Amorin AKMA, França A. Sentidos da Saúde numa perspectiva do Gênero: um estudo com homens da cidade de Natal/RN. Psicol Ciênc Prof [Internet]. 2016 [cited 2016 Apr 14];36(2):341-53. Available from: http:// www.scielo.br/pdf/pcp/v36n2/1982-3703-pcp-36-2-0341.pdf

15. Brasil. Ministério da Saúde. Secretaria de Atenção à Saúde. Departamento de Ações Programáticas e Estratégicas. Política Nacional de Atenção Integral à Saúde do Homem: princípios e diretrizes. Brasília, DF: Ministério da Saúde; 2008

16. Rodrigues JD, Cruz MS, Paixão AN. Uma análise da prevenção do câncer de mama no Brasil. Cienc Saúde Colet [Internet]. 2015 [cited 2016 Sep 5];20(10):3163-76. Available form: http://www.scielo.br/pdf/csc/v20n10/1413-8123-csc-20-10-3163.pdf

17. Brasil. Instituto Brasileiro de Geografia e Estatística, Ministério da Saúde, Fundação Oswaldo Cruz. Pesquisa Nacional de Saúde 2013: percepção do estado de saúde, estilos de vida e doenças crônicas: Brasil, grandes regiões e unidades da federação [Internet]. Rio de Janeiro: IBGE; 2014 [cited 2016 Sep 5]. Available from: http://portalsaude.saude.gov.br/images/pdf/2015/agosto/24/PNSVolume-1-completo.pdf

18. Zamboni MM, Silva Junior CT, Baretta R, Cunha ET, Cardoso GP. Fatores prognósticos para a sobrevida dos pacientes com derrame pleural maligno. Pulmão RJ [Internet]. 2016 [cited 2016 Jul 1];25(1):43-52. Available from: http://www.sopterj.com.br/ profissionais/_revista/2016/n_01/11-fatores-prognosticos-para-a-sobrevida-dos-pacientes-com-derrame-pleural-maligno.pdf 